\title{
JAKOŚCIOWA ANALIZA DZIAŁAŃ STOWARZYSZENIA NIEZALEŻNA INICJATYWA RODZICÓW I POŁOŻNYCH „DOBRZE URODZENI" NA RZECZ WSPIERANIA POZYTYWNEGO DOŚWIADCZENIA PORODOWEGO
}

\section{WELL BORN! - ANALYSIS OF ACTIONS OF INDEPENDENT INITIATIVE OF PARENTS' AND MIDWIFES' FOR SUPPORT OF POSITIVE BIRTH EXPERIENCE}

\author{
Barbara Baranowska', Ewelina Kościk², Grażyna Bączek', Urszula Tataj-Puzyna', Magdalena Krauze', \\ Dorota Sys ${ }^{3}$, Beata Pięta ${ }^{4}$ \\ 'Zakład Dydaktyki Ginekologiczno-Położniczej, Warszawski Uniwersytet Medyczny \\ ${ }^{2}$ Specjalistyczny Szpital Wojewódzki w Ciechanowie \\ ${ }^{3}$ Zakład Zdrowia Prokreacyjnego Centrum Medycznego Kształcenia Podyplomowego w Warszawie \\ ${ }^{4}$ Zakład Praktycznej Nauki Położnictwa, Uniwersytet Medyczny im. Karola Marcinkowskiego w Poznaniu \\ DOI: https://doi.org/10.20883/ppnoz.2019.20
}

\section{STRESZCZENIE}

Wstęp. Pozytywne doświadczenie porodowe matek jest obecnie przedstawiane przez Światową Organizację Zdrowia jako priorytet w opiece okołoporodowej. Stowarzyszenie Niezależna Inicjatywa Rodziców i Położnych "Dobrze Urodzeni” działa w wielu obszarach na rzecz wspierania porodu jako naturalnego, bezpiecznego i pięknego sposobu przychodzenia dziecka na świat.

Cel. Celem pracy było przedstawienie wielokierunkowych działań Stowarzyszenia, wspierających pozytywne doświadczenia porodowe kobiet.

Materiał i metody. Badania przeprowadzono metodą jakościową. Narzędzie badawcze stanowiły pogłębione wywiady z członkami Stowarzyszenia, obserwacja oraz analiza dokumentacji Stowarzyszenia.

Wyniki. Stowarzyszenie kieruje ofertę zarówno do kobiet - przyszłych matek, jak i do położnych. Głównym celem pracy członków Stowarzyszenia jes zwiększanie szansy na przeżycie bezpiecznego, satysfakcjonującego porodu. Drugim obszarem jest promowanie zawodu położnej. Wiele działań podejmowanych przez Stowarzyszenie wspiera wiedzę i umiejętności położnych (np. organizacja szkoleń, konferencji).

Wnioski. Tworzenie środowiska niezależnych położnych, wspieranie samodzielności położnych, dostarczanie rodzicom informacji na temat naturalnego porodu przez Stowarzyszenie stanowią ważny element wspierania pozytywnego doświadczenia porodowego.

Słowa kluczowe: poród, położnictwo, położna, stowarzyszenie.

ABSTRACT

Introduction. Positive maternal labor experience is currently presented by the World Health Organization as a priority in perinatal care. Association: Parent and Midwife Independent Initiative "Well Born" works in many areas to support childbirth as a natural, safe and beautiful way of child's coming to the world.

Aim. The aim of the work is to present the Association's multidirectional activities that support women's the positive labor experience.

Material and methods. Studies were carried out using the qualitative method. The research tool consisted of in-depth interviews with members of the Association, observation and analysis of the Association's documentation.

Results. The Association is targeting both women - future mothers and midwives. The main goal of the Association members' work is to increase the chance to experience a safe, satisfying birth. The second area is promoting the midwife profession. Many activities undertaken by the Association support midwives' knowledge and skills (e.g. organization of trainings, conferences).

Conclusions. Creating an environment of independent midwives, supporting their self-reliance, providing parents with information about the natural birth by the Association, are important elements of supporting positive childbirth experience.

Keywords: childbirth, obstetrics, midwife, association.

\section{Wstęp}

"Żyjemy w dobie, kiedy określenie "dobrze urodzony" nabrało nowej treści. Obecnie nie wystarcza już pragnienie, aby dziecko urodziło się żywe. Chcemy zaoszczędzić mu wszelkich dających się uniknąć trudności porodowych, aby w przyszłości nie było "trudnym" dzieckiem obarczonym urazem porodowym. Nazywamy to dobrym porodem. Wszystkie dzieci maja prawo być dobrze urodzone".

Prof. Włodzimierz Fijatkowski 
Przez wieki wydarzenia związane z ciążą i porodem stanowiły niezwykle ważną część życia całych społeczności, stanowiły bowiem symbol ich ciągłości. Z narodzinami stanowiącymi rytuał przejścia wiązały się rytuały i obrzędy, a kwestie takie jak dobór miejsca, pozycji czy osoby towarzyszącej w porodzie, sposób traktowania matki i noworodka, kształtowane były przez normy społeczne, kulturowe i religijne. Stopniowo, równolegle z rozwojem medycyny i dostępem do nowoczesnego sprzętu i leków, narodziny zaczęto przenosić do szpitali. Proces ten miał na celu zwiększenie bezpieczeństwa matki i dziecka, doprowadził jednak niejako do zmiany postrzegania tych naturalnych chwil w życiu ludzi przez pryzmat patologii. $W$ dużej mierze wykluczono najbliższych z udziału w narodzinach, wprowadzając jednocześnie rutynowo stosowane, szpitalne procedury. Rezultatem medykalizacji porodu, skojarzenia go z bólem i chorobą, a także przeniesienia go do murów szpitala okazało się zdominowanie położnictwa przez lekarzy, a co za tym idzie, również marginalizacja zawodu położnej [1].

Jakość porodu ma wielkie znaczenie dla przyszłego zdrowia matki i dziecka, co potwierdzają nie tylko badania epidemiologiczne, ale doniesienia z zakresu epigenetyki i wiedzy o ludzkim mikrobiomie [2-6].

W ciągu ostatnich lat medykalizacja porodu coraz częściej poddawana jest krytyce [7-10]. Pojawiają się głosy, że równolegle ze zmianami w systemie opieki okołoporodowej na szczeblu instytucjonalnym powinno się podjąć dyskusję na temat praw kobiet [11]. Światowa Organizacja Zdrowia promuje model opieki okołoporodowej, w którym za prowadzenie ciąży fizjologicznej, opiekę nad kobietą w porodzie i połogu oraz dzieckiem odpowiada położna. Ten model obowiązuje obecnie w wielu krajach Europy [12]. Do wspierania tego modelu opieki odnośni się też seria publikacji w prestiżowym czasopiśmie Lancet [13].

Pewną trudnością wydaje się połączenie nowoczesnych zdobyczy medycyny z tradycyjnym położnictwem opartym na zaufaniu naturze i samej kobiecie. Wyzwanie to podjęło Stowarzyszenie Niezależna Inicjatywa Rodziców i Położnych "Dobrze Urodzeni”. Głównym obszarem zainteresowania wspomnianej organizacji pożytku publicznego jest wspieranie rodziców $w$ ich rodzicielstwie, budowanie pozytywnego doświadczenia porodowego, a także podnoszenie prestizu zawodowego położnych, zwłaszcza pracujących w sposób niezależny.

\section{Materiał i metoda}

Głównym celem pracy było przedstawienie działalności Stowarzyszenia Niezależnej Inicjatywy Rodziców i Położ- nych „Dobrze Urodzeni” w kontekście wspierania pozytywnego doświadczenia porodowego i promowania dobrego porodu. Praca ma charakter jakościowy. Ze względu na charakter opisywanego zjawiska, zastosowano metody badawcze, takie jak wywiady pogłębione, obserwację oraz analizę dokumentacji. Narzędzie badawcze stanowił kwestionariusz wywiadu, arkusz analizy dokumentacji i obserwacji. Badania zrealizowano w okresie od lipca 2017 r. do lutego $2018 \mathrm{r}$. Wywiady pogłębione przeprowadzano osobiście lub telefonicznie. Czas trwania rozmów wynosił 40 - 90 minut. Wywiady były nagrywane i transkrybowane. Badanych pytano o historię, działalność stowarzyszenia, a także o rozumienie bycia "dobrze urodzonym".

Wszyscy respondenci byli członkami Stowarzyszenia Niezależnej Inicjatywy Rodziców i Położnych „Dobrze Urodzeni". W grupie badanej znalazła się prezeska, dwie wiceprezeski oraz skarbniczka Stowarzyszenia. Badane wykonywały zawód położnej, douli, konsultantki laktacyjnej i coacha.

\section{Wyniki}

\section{Przyczyny powstania i główne idee}

Stowarzyszenie Niezależna Inicjatywa Rodziców i Położnych powstało w 2005 r. W gronie 15 członków założycieli - rodziców i położnych - znalazły się osoby, którym bliski był temat jakości opieki okołoporodowej. Wśród motywacji członków do utworzenia Stowarzyszenia można wyróżnić bowiem dwa nurty. Pierwszy formalno-prawny, dążący do uporządkowania sytuacji porodów domowych w Polsce, drugi - wspierający rozwój zawodowy i osobisty położnych. Od 2012 r. Stowarzyszenie posiada status Organizacji Pożytku Publicznego.

Główne cele stowarzyszenia "Dobrze Urodzonych" skupiają się wokół umożliwiania rodzicom i dzieciom satysfakcjonującego porodu oraz promowania zawodu położnej. Stowarzyszenie działa, aby stworzyć rodzicom możliwość swobodnego wyboru sposobu oraz miejsca porodu. Członkowie organizacji podejmują działania na szeroką skalę, angażując się m.in. w powstawanie oddziałów położniczych prowadzonych przez położne i domów narodzin, a także udzielając im stosownych rekomendacji. Jednocześnie próbują wpływać na społeczne postrzeganie porodów pozaszpitalnych tak, aby mogły one w pełni zaistnieć w polskim systemie opieki okołoporodowej, nie narażając tym samym rodziców na ostracyzm.

Grupa członków Stowarzyszenia od momentu jego powstania rozrosła się z 15 do 75 osób. Tworzą je przede wszystkim położne, ale również doule, psycholodzy, ratownicy medyczni. Członkowie Stowarzyszenia mogą 
aktywnie uczestniczyć we wszystkich jego działaniach, a dzięki prawu wyborczemu aktywnie wpływać na jego strategię

\section{Działalność}

Jednym z pierwszych osiągnięć Stowarzyszenia „Dobrze Urodzeni" było uporządkowanie sytuacji porodów domowych w Polsce. Położne niezależne zrzeszone w Stowarzyszeniu podjęły się, jako pierwsze i jedyne w Polsce, stworzenia jednolitej dokumentacji porodu domowego umowy o świadczenie usług położniczych okołoporodowych, karty kwalifikacji do porodu w domu, karty porodu w domu, karty informacyjnej porodu w domu oraz arkusza wizyty po porodzie. Opracowały również zasady kwalifikacji do porodu domowego oraz model opieki nad kobietą i dzieckiem w fizjologicznym okresie okołoporodowym w praktyce pozaszpitalnej.

Umowa o świadczenie usług położniczych okołoporodowych jest umową cywilno-prawną zawieraną pomiędzy położną (posiadającą aktywne Prawo Wykonywania Zawodu oraz prowadzącą działalność gospodarczą w zakresie położnictwa ogólnego) a klientką (kobietą ciężarną decydującą się na poród w domu pod opieką wybranej położnej). Umowa w jasny i szczegółowy sposób określa prawa oraz obowiązki każdej ze stron, nie tylko w zakresie przebiegu samego porodu, ale także dojazdu do miejsca porodu, postępowania w przypadku wystąpienia komplikacji lub patologii porodu, zasad wynagrodzenia położnej, jej ewentualnego zastępstwa czy udziału osób trzecich.

Karta kwalifikacji do porodu domowego opracowana została na podstawie zasad zawartych w "Modelu opieki nad kobietą i dzieckiem w fizjologicznym okresie okołoporodowym w praktyce pozaszpitalnej", opracowanym przez Sekcję Położnych Niezależnych przy Stowarzyszeniu „Dobrze Urodzeni” [14].

Kolejnym elementem dokumentacji stworzonej przez "Dobrze Urodzonych" jest karta porodu w domu. Położna zamieszcza $w$ niej informacje z przebiegu porodu, w tym dane dotyczące stanu matki i noworodka, zgodnie z obowiązującymi na podstawie umowy cywilno-prawnej obowiązkami. Z kolei karta informacyjna porodu $w$ domu jest swojego rodzaju odpowiednikiem karty informacyjnej z leczenia szpitalnego i zawiera dane takie jak liczba ciąż i porodów przebytych przez kobietę, tydzień ciąży, w którym odbył się obecny poród, grupa krwi matki, położenie, ustawienie i ułożenie płodu, przebieg połogu z oceną krocza i laktacji. W dokumencie zaleca się także rejestrację dziecka w Urzędzie Stanu Cywilnego odpowiednim do miejsca urodzenia dziecka, zgłoszenie dziecka pod opiekę pediatry oraz wraz z matką pod opiekę po- łożnej środowiskowo-rodzinnej, kontrolną wizytę kobiety u lekarza ginekologa 6 tygodni po porodzie oraz oznaczenie morfologii krwi.

Zasady kwalifikacji do porodu domowego określone przez Stowarzyszenie „Dobrze Urodzeni” są bardzo restrykcyjne, a położne zrzeszone zobowiązane są do ich przestrzegania. Jednocześnie położne mają prawo odmówić zawarcia umowy na opiekę okołoporodową w warunkach pozaszpitalnych, np. jeśli stwierdzą, że kobieta lub jej partner nie są na to psychicznie gotowi.

$\mathrm{Na}$ stronie internetowej Stowarzyszenia zamieszczona jest wyszukiwarka położnych, z podziałem na województwa, zajmujących się: prowadzeniem ciąży (również równolegle z lekarzem), edukacją okołoporodową $w$ formie indywidualnego przygotowania do porodu lub grupowych zajęć w szkole rodzenia, wizytami patronażowymi do 6 . tygodnia po porodzie, doradztwem laktacyjnym, indywidualną opieką okołoporodową w szpitalu, wsparciem jako osoba towarzysząca, pielęgniarstwem rodzinnym w ramach podstawowej opieki zdrowotnej, a także prowadzeniem porodu w domu. Tą ostatnią aktywność realizuje około dwudziestu dwóch położnych zrzeszonych w Stowarzyszeniu.

Kolejną sferą zainteresowań Stowarzyszenia „Dobrze Urodzeni" jest wspieranie niezależności zawodowej położnych na płaszczyźnie intelektualnej i emocjonalnej. Aby kobiety mogły doświadczać dobrego porodu, otrzymywać właściwą opiekę i wsparcie, sprawujące ją położne potrzebują stałego doskonalenia swej wiedzy, możliwości wymiany doświadczeń z innymi i odpowiednich rozwiązań systemowych, aby pracować w godnych i satysfakcjonujących warunkach. Szeroka, interdyscyplinarna wiedza jest niewątpliwie jedną z oznak profesjonalizmu, a więc niezbędnym krokiem do osiągnięcia niezależności zawodowej. Stowarzyszenie od lat zajmuje się edukacją osób interesujących się tematyką narodzin poprzez organizowanie konferencji i szkoleń oraz wydawanie publikacji.

Poza różnego rodzaju formami edukacji położnych, Stowarzyszenie "Dobrze Urodzeni”, od 2015 r., we współpracy z Fundacją Mustela realizuje pierwszy w Polsce projekt finansowania badań naukowych $w$ dziedzinie położnictwa. Stypendium mogą otrzymać wyłącznie położne. Projekt ma na celu poprawę stanu zdrowia okołoporodowego oraz wsparcie położnych w zakresie badań medycznych i opracowywania zaleceń dla praktyki klinicznej.

Jednym z czynników zewnętrznych wpływających na niezależną pracę położnych jest świadomość społeczeństwa na temat roli położnej w systemie opieki okołoporodowej. Stowarzyszenie "Dobrze Urodzeni" jest jednym z partnerów merytorycznych prowadzonej w Polsce od 
2014 roku kampanii „Położna na medal”. W ramach kampanii kobiety informowane są o możliwości skorzystania z konsultacji z położną przygotowujących do porodu raz na tydzień po 21. tygodniu ciąży i 2 razy - po 32. tygodniu. Promowane są także standardy opieki okołoporodowej zgodne z wymaganiami natury medycznej oraz oczekiwaniami samych kobiet. Część kampanii stanowi plebiscyt, w którym raz do roku wybierane są najlepsze położne w kraju oraz w poszczególnych województwach.

Niezależna praca, zwłaszcza przyjmowanie porodów domowych, wciąż naraża położne na niechęć ze strony środowiska zawodowego, jest to też duże wyzwanie w organizacji życia rodzinnego. Na stronie internetowej Stowarzyszenia znajduje się sfera dostępna jedynie dla jego członków. Jest to miejsce, gdzie położne niezależne mogą wymieniać doświadczenia, dzielić się wątpliwościami, przykrymi doświadczeniami, a jednocześnie otrzymać wsparcie w trudnej sytuacji zawodowej, niejednokrotnie również osobistej.

Stowarzyszenie "Dobrze Urodzeni" poprzez swoją działalność zyskało pewne zaufanie ze strony środowiska medycznego. Skutkiem tego Stowarzyszenie stało się organem opiniotwórczym w zakresie opieki okołoporodowej na szczeblu nie tylko medialnym, ale również instytucjonalnym.

Przedstawiciele Stowarzyszenia od kilku lat biorą udział w spotkaniach dotyczących opieki okołoporodowej w Ministerstwie Zdrowia. W 2015 r. Zarządzeniem Ministra Zdrowia, w odpowiedzi na brak odpowiednich narzędzi do monitorowania i skutecznego wprowadzania zmian w związku z tzw. standardami opieki okołoporodowej, powołano Zespół do spraw monitorowania i opracowania rozwiązań na rzecz poprawy opieki okołoporodowej. Wśród 19 członków zespołu znalazła się również wiceprezeska Stowarzyszenia "Dobrze Urodzeni”.

Stowarzyszenie "Dobrze Urodzeni" wyraziło w formie petycji swój sprzeciw wobec zmian w ustawie o Podstawowej Opiece Zdrowotnej, tzn. wspólnego kontraktowania przez jednego świadczeniodawcę świadczeń leżących w zakresie kompetencji położnej, lekarza i pielęgniarki. Zdaniem członków Stowarzyszenia, wprowadzenie wspólnej deklaracji wyboru i zespołów lekarsko-pielęgniarskich ograniczyłoby znacznie samodzielność zawodową pielęgniarek i położnych, a także indywidualnych i grupowych praktyk zawierających umowy na realizację świadczeń zdrowotnych z Narodowym Funduszem Zdrowia.

Stowarzyszenie wywiera wpływ na jakość opieki okołoporodowej również poprzez certyfikację szkół rodzenia i domów narodzin w Polsce. Udział w procedurze certyfikacji jest zupetnie dobrowolny, a sam certyfikat stanowi potwierdzenie, że w danym ośrodku wykazuje się indywidualne podejście do osób oczekujących narodzin dziecka oraz pragnących swobodnego wyboru sposobu i miejsca rodzenia, a także propaguje się wiedzę i umiejętności w opiece nad noworodkiem.

Stowarzyszenie prowadzi jedyne w kraju statystki dotyczące porodów pozaszpitalnych gromadzone i opracowane na podstawie dokumentacji medycznej z porodów odbywających się $w$ domu kobiety $w$ asyście położnych ze Stowarzyszenia od 2010 do 2015 r. [15]

Statystyki opracowane przez położne zrzeszone w "Dobrze Urodzonych" nie tylko pomagają oszacować skalę działalności samego Stowarzyszenia, ale mogą też stanowić punkt odniesienia w dyskusji pomiędzy zwolennikami a przeciwnikami porodów pozaszpitalnych w Polsce. W pewnym stopniu dowodzą bowiem bezpieczeństwa porodu domowego przy odpowiednio przeprowadzonej kwalifikacji.

\section{Czym jest "dobre urodzenie"?}

Badani proszeni byli o opisanie, czym dla nich jest dobry poród, dobre przychodzenie na świat. W większości wypowiedzi zaznaczali, że pozytywne doświadczenie porodowe dotyczy się takiego przebiegu porodu, jaki był oczekiwany przez rodziców dziecka. Badani zaznaczali, że nie samo miejsce przychodzenia na świat czyni doświadczenie porodu pozytywnym. Można pięknie i z satysfakcją spełnionych oczekiwań urodzić drogą cięcia cesarskiego, a także w sposób nieplanowany, w wielkim stresie i poczuciu zagrożenia urodzić naturalnie $w$ domu. W wypowiedziach badanych dominuje opinia, że to właśnie odczucie kobiety i jej percepcja doświadczenia porodowego jest kluczowa w końcowym określeniu jakości porodu.

Dobry poród to taki, który jest dobry dla konkretnej kobiety w danej sytuacji, spełniajacy jej oczekiwania. Dobrym porodem może okazać się również cięcie cesarskie w sytuacji, gdy żaden inny sposób rozwiqzzania ciąży nie wchodzi w grę (EDP, położna)

"Dobrze urodzony" to urodzony w najlepszy dla niego sposób, z wykorzystaniem wszystkich możliwości tej matki i tego dziecka w danym momencie" (KO, położna)

"Dobry poród" to niekoniecznie poród w domu, może to być też piękny poród szpitalny, a nawet cesarskie cięcie. Odczucie porodu to ważny filar w przyszłym rozwoju dziecka, ale nie jedyny - każde trudne doświadczenie można przekuć w coś dobrego, tak jak to było w jej przypadku" (MO, psycholog, konsultant laktacyjny, instruktor szkoły rodzenia)

Badane podkreślały, że istotnym elementem dobrego porodu jest uwzględnienie godności. Jedna z nich pisze, że 
urodzić się dobrze, to (...) urodzić się w atmosferze miłości i spokoju, w poszanowaniu godności i szacunku należnym godzinom rodzenia się małego człowieka. Dobre narodziny to przejście z ukrycia istoty ludzkiej utkanej przez Boga $w$ tonie matki w otwarte ramiona obydwojga rodziców. (IC, połozina)

"Dobrze urodzony" to ten, który przychodzi na świat w warunkach godnych dla siebie. (MM, coach zdrowia)

Być "dobrze urodzonym" znaczy urodzić się w warunkach maksymalnego poszanowania godności i intymności, szacunku, jedności matki z dzieckiem, być potraktowanym z delikatnościq, z zastosowaniem procedur medycznych tylko, gdy sq one potrzebne, ale bez ingerowania wtedy, gdy nie ma takiej konieczności. (MO, psycholog, konsultant laktacyjny, instruktor szkoły rodzenia)

Badane też wskazują na znaczenie sprzyjających warunków, otoczenia i towarzyszącego rodzącej personelu.

Być "dobrze urodzonym" to przyjśś na świat w korzystnych dla siebie i mamy warunkach, z minimalizacją stresu iniepotrzebnej medykalizacji, w otoczeniu przyjaźnie nastawionych osób sprawujących opiekę. (EDP, położna)

"Dobrze urodzone" dziecko to takie, które przychodzi na świat w atmosferze mitości i szacunku, w warunkach, które wybrata matka. Kobiety rodzace potraktowane w pełni osobowo, podmiotowo, z odpowiednim poziomem wrażliwości i empatii, nawet w sytuacji porodu przebiegającego niezgodnie z ich wymarzonym scenariuszem - moga mieć poczucie, że poród nie zostat im odebrany. (MH, położna, doula)

\section{Dyskusja}

Pozytywne doświadczenie porodowe dla matki i dziecka jest coraz częściej wymieniane jako ważne kryterium jakości opieki porodowej [16]. Sposób przychodzenia na świat ma kluczowe znaczenie w kontekście przyszłego zdrowia zarówno dziecka, jak i matki [17]. Stowarzyszenie „Dobrze Urodzeni" realizuje działania na rzecz wspierania dobrych narodzin. Na świecie podobne zadania wypełniają organizację takie jak The European Network of Childbirth Associations czy The American Association of Birth Centers $[18,19]$

Światowa Organizacja Zdrowia promuje model opieki okołoporodowej, w którym za prowadzenie ciąży fizjologicznej, opiekę nad kobietą w porodzie i połogu oraz dzieckiem odpowiada położna [16]. Ten model obowiązuje obecnie w wielu krajach Europy [20]. Badane Stowarzyszenie w sposób aktywny wspiera rozwój położnych i wzmacnia ich kompetencję w opiece nad matką i dzieckiem.

Właśnie opieka położnych wymieniana jest jako jeden z elementów wpływających na promowanie naturalnego porodu, a tym samym ograniczanie jego medykalizacji. W Polsce problem medykalizacji narodzin jest wciąż aktualny [21, 22]. Działania Stowarzyszenia przyczyniają się do poprawy $w$ tym obszarze.

Jednym z elementów zapewnienia kobietom dobrego doświadczenia porodowego jest umożliwienie im prawa do wyboru miejsca do porodu. Dzięki działalności opisywanego Stowarzyszenia wybór ten staje się dostępny dla coraz większej liczby kobiet, choć nadal jest to całkowicie alternatywne rozwiązanie. Zgodnie z danymi udostęp nionymi w Roczniku Demograficznym 2017 przez Główny Urząd Statystyczny, w 2016 roku było 382471 żywych urodzeń, z czego 657 - czyli 0,17\% dzieci urodziło się poza szpitalem [23].

Porody domowe mają w założeniu zapewnić kobiecie odpowiednie warunki i środowisko, by w poczuciu bezpieczeństwa i bliskości własnej rodziny wydać dziecko na świat [24]. Również porody w domach narodzin promowane przez niezależne położne mają umożliwić kobiecie rodzenie w otoczeniu przypominającym domowe warunk i zapewniające profesjonalną opiekę położnych. W wielu krajach model opieki nad kobietą w ciąży niskiego ryzyka oferowany jest w systemie pozaszpitanym, będącym elementem systemu ochrony zdrowia [25]. W wielu krajach Europy porody $w$ domu funkcjonują $w$ systemach opiek okołoporodowej na równi z porodami szpitalnymi [26].

Stowarzyszenie Niezależna Inicjatywa Rodziców i Położnych "Dobrze Urodzeni” podjęło próbę przywrócenia porodom domowym miejsca w polskim systemie opiek okołoporodowej. Położne zrzeszone $w$ organizacji samodzielnie opracowały zasady kwalifikacji, dokumentację oraz model opieki nad kobietą i dzieckiem w porodzie domowym. Od wielu lat przyjmują porody domowe w Polsce, a zebrane przez nie statystyki - jak dotąd jedyne w naszym kraju - mogą dowodzić bezpieczeństwa porodu pozaszpitalnego, o ile kwalifikacja odbywa się z odpowiednią rozwagą i pieczołowitością. Teraz bowiem mamy lepsze niż dawniej narzędzia i wiedzę - możemy przeprowadzić badania laboratoryjne, obrazowe, sporządzić statystyk i porównania, ocenić, jakie postępowanie jest najbezpieczniejsze, najbardziej właściwe i akceptowalne dla kobiety.

Położne zrzeszone w Stowarzyszeniu Niezależnej Inicjatywy Rodziców i Położnych "Dobrze Urodzeni” swoją pracą dowiodły, że położne w Polsce posiadają wszelką wiedzę i umiejętności, aby pracować w sposób niezależny i uczestniczyć w aktywnym kształtowaniu opieki okołoporodowej. Członkinie Stowarzyszenia, poprzez łączącą je pasję, wiedzę, umiejętności, ale też wspólny cel - chęć przywrócenia zawodowi położnej dawnej świetności, a momentowi narodzin należnej mu godności, niezależnie 
od miejsca i rodzaju porodu - mogą stanowić wzór jedności zawodowej. Idealnie byłoby, aby coraz więcej położnych przyłączało się do Stowarzyszenia "Dobrze Urodzeni”. Łącząc siły, można zrobić więcej, aby każda kobieta w Polsce mogła urodzić dziecko bezpiecznie, bez traumy, w sposób dla siebie i dziecka najbardziej właściwy - urodzić dobrze.

\section{Wnioski}

1. Stowarzyszenie "Dobrze Urodzeni” aktywnie działa na rzecz naturalnych, skoncentrowanych na kobiecie i jej rodzinie porodów.

2. Wkład Stowarzyszenia w podniesienie jakości opieki okołoporodowej pozaszpitalnej, poprzez tworzenie jednolitej dokumentacji, udzielanie wsparcie i kształcenie personelu pracującego $w$ domach czy domach narodzin jest znaczący.

3. Działania Stowarzyszenia promują pozytywne doświadczenie porodowe.

\section{Oświadczenia}

Oświadczenie dotyczace konfliktu interesów

Autorzy deklarują brak konfliktu interesów.

\section{Źródła finansowania}

Autorzy deklarują brak źródeł finansowania.

\section{Piśmiennictwo}

1. Nowakowska L. Reflections on Pregnancy and Childbirth. The Perspective of Critical Discourse Analysis. Cult-Soc-Educ. 2014;(1):9-24. http://cejsh.icm.edu.pl/cejsh/element/ bwmeta1.element. desklight-ab13fcce-9245-4b48-9ead7707bdac0e9e.

2. Indrio F, Martini S, Francavilla R, Corvaglia L, Cristofori $F_{\text {, }}$ Mastrolia SA, i in. Epigenetic Matters: The Link between Early Nutrition, Microbiome, and Long-term Health Development. Front Pediatr. 2017;5:178. https://doi.org/10.3389/ fped.2017.00178.

3. Magne F, Puchi Silva A, Carvajal B, Gotteland M. The Elevated Rate of Cesarean Section and Its Contribution to Non-Communicable Chronic Diseases in Latin America: The Growing Involvement of the Microbiota. Front Pediatr. 2017;5:192. https://doi.org/10.3389/fped.2017.00192.

4. Moore SR, McEwen LM, Quirt J, Morin A, Mah SM, Barr RG, $\mathrm{i}$ in. Epigenetic correlates of neonatal contact in humans. Dev Psychopathol. 2017;29(05):1517-1538. https://doi. org/10.1017/S0954579417001213

5. Moya-Pérez A, Luczynski P, Renes IB, Wang S, Borre $Y$, Anthony Ryan $C$, $i$ in. Intervention strategies for cesarean section-induced alterations in the microbiota-gut-brain axis. Nutr Rev. 2017;75(4):225-240. https://doi.org/10.1093/ nutrit/nuw069.

6. Younes JA, Lievens E, Hummelen R, van der Westen R, Reid G, Petrova MI. Women and Their Microbes: The Unexpected Friendship. Trends Microbiol. 2017;22(1):16-32. https://doi. org/10.1016/j.tim.2017.07.008.

7. Indraccolo U, Calabrese S, Di lorio R, Corosu L, Marinoni E, Indraccolo SR. Impact of the medicalization of labor on mode of delivery. Clin Exp Obstet Gynecol. 2010;37(4):273-7.
8. Mobarakabadi SS, Najmabadi KM, Tabatabaie MG, Esmaily $H$. Predictors of mode of childbirth based on medicalized maternal care: A cross-sectional study. Iran Red Crescent Med J [Internet]. 2017;19(2). http://cdn.neoscriber.org/ cdn/serve/313ea/beedd839c8d3ba80eb13b8c35914f717dc 86a559/16604-pdf.pdf.

9. Moura FM, Crizostomo CD, Nery IS, Mendonça RC, de Araújo $\mathrm{OD}$, da Rocha SS. Humanization and nursing assistance to normal childbirth. Rev Bras Enferm. 2007;60(4):452-5. https://cdn.neoscriber.org/cdn/serve/313ea/beedd839c8 d3ba80eb13b8c35914f717dc86a559/16604-pdf.pdf.

10. Shaw JCA. The Medicalization of Birth and Midwifery as Resistance. Health Care Women Int. 2013;34(6):522-36. https://doi.org/10.1080/07399332.2012.736569.

11. Doroszewska A. Medicalization of delivery in Poland. Report on the monitoring of maternity wards. Warsaw, Poland: Childbirth with Dignity Foundation; 2017

12. Tunçalp Özge, Pena-Rosas JP, Lawrie T, Bucagu M, Oladapo OT, Portela A, i in. WHO recommendations on antenatal care for a positive pregnancy experience-going beyond survival. BJOG Int J Obstet Gynaecol. 2017;124(6):860-862. https:// doi.org/10.1111/1471-0528.14599.

13. Homer CS, Friberg IK, Dias MAB, ten Hoope-Bender P, Sandall J, Speciale AM, i in. The projected effect of scaling up midwifery. The Lancet. 2014;384:1146-57. https://doi.org/10.1016/ S0140-6736(14)60790-X.

14. Dzierżak-Postek E, Grzybowska K, Krauze M, Oleś K, Romanowska M, Witkiewicz M. Model opieki nad kobietą i dzieckiem w fizjologicznym okresie okołoporodowym w praktyce pozaszpitalnej. Położ Nauka Prakt. 2010;4:8-19. http://www. dobrzeurodzeni.pl/model-opieki-okoloporodowej.html.

15. Krauze M. Opracowanie statystyczne porodów domowych przyjętych w latach 2010-2015 przez położne zrzeszone w Stowarzyszeniu "Dobrze Urodzeni" [Internet]. Stowarzyszenie Nlezależna Inicjatywa Rodziców i Położnych „Dobrze Urodzeni"; 2015 s. 1-5. Dostępne na: http://www.dobrzeurodzeni.pl/statystyki.html.

16. World Health Organization. WHO |WHO recommendations: intrapartum care for a positive childbirth experience [Internet]. WHO. 2018 [cytowane 13 marzec 2018]. Dostępne na: http://www.who.int/reproductivehealth/publications/ intrapartum-care-guidelines/en/.

17. Baranowska B, Kubicka-Kraszyńska. Quality of childbirth in scientific research. W Poland, Warsaw: Childbirth with Dignity Foundation; 2009. s. 14-20.

18. Beech BL. European Network of Childbirth Associations (ENCA) meeting 2004. AIMS J. 2004;16:18-18.

19. Phillippi JC, Alliman J, Bauer K. The American Association of Birth Centers: History, Membership, and Current Initiatives. J Midwifery Women's Health. 10 wrzesien 2009;54(5):38792. https://doi.org/10.1016/j.jmwh.2008.12.009.

20. Iwanowicz-Palus GJ, Stadnicka G, Bien A. Organizacja opieki przedkoncepcyjnej i okołoporodowej determinantą zdrowia rodziny i społeczeństwa. Med Ogólna Nauki O Zdrowiu. 2013;19(3). http://yadda.icm.edu.pl/yadda/element/bwmeta1.element.agro-96620629-1732-42a3-986f-29d0b810ad55.

21. Doroszewska A. Opieka okołoporodowa w Polsce po trans formacji ustrojowej - między medykalizacją a demedykalizacją? Ann Univ Mariae Curie-Sklodowska Sect I-Philosophia-Sociol. 2017;41(2):47. https://doi.org/10.17951/ i.2016.41.2.47.

22. Doroszewska A. Medykalizacja porodu w Polsce. Raport z monitoringu oddziałów położniczych. Warszawa: Fundacja Rodzić po Ludzku; 2017 s. 78. 
23. Rocznik demograficzny. Główny Urząd Statystyczny; 2017 https://stat.gov.pl/obszary-tematyczne/roczniki-statystyczne/roczniki-statystyczne/rocznik-demograficzny2017,3,11.html.

24. O'Boyle C. 'Just waiting to be hauled over the coals': Home birth midwifery in Ireland. Midwifery. 2013;29(8):988-995 https://doi.org/10.1016/j.midw.2012.12.010.

25. Fawsitt CG, Bourke J, Lutomski JE, Meaney S, McElroy B, Murphy $R_{1} i$ in. What women want: Exploring pregnant women's preferences for alternative models of maternity care. Health Policy. 2017;121:66-74. https://doi.org/10.1016/j. healthpol.2016.10.010.

26. Schroeder E, Petrou S, Patel N, Hollowell J, Puddicombe $D_{t}$ Redshaw $\mathrm{M}, \mathrm{i}$ in. Cost effectiveness of alternative planned places of birth in woman at low risk of complications: evidence from the Birthplace in England national prospective cohort study. Bmj. 18 kwiecień 2012;344:e2292. https://doi. org/10.1136/bmj.e2292.

Zaakceptowano do edycji: 20.08.19 Zaakceptowano do publikacji: 26.09.19

Adres do korespondencji:

Barbara Baranowska

ul. Żwirki i Wigury 81

02-091 Warszawa

tel. 509-083-263

e-mail: bbaranowska@gmail.com 